\title{
Brand-Related eWOM and Its Effects on Purchase Decisions: An Empirical Study of University of Botswana Students
}

\author{
Godfrey Themba ${ }^{1} \&$ Monica Mulala ${ }^{1}$ \\ ${ }^{1}$ Department of Marketing, University of Botswana, Gaborone, Botswana \\ Correspondence: Godfrey Themba, Department of Marketing, University of Botswana, Private bag 0022 , \\ Gaborone, Botswana. Tel: 267-355-2980. E-mail: thembag@mopipi.ub.bw
}

Received: December 7, 2012

Accepted: February 6, 2013 Online Published: March 13, 2013

doi:10.5539/ijbm.v8n8p31

URL: http://dx.doi.org/10.5539/ijbm.v8n8p31

\begin{abstract}
This research investigates the extent to which University of Botswana students engage in brand-related eWOM via social media and the effects this could be having on their purchase decisions. A survey method involving a structured questionnaire administered to a convenience sample of 300 students at the main campus of the University of Botswana was used. Unexpectedly the results of the present study indicate that the level of engagement in brand-related eWOM by University of Botswana students is relatively low. The results also indicate that engagement in brand-related eWOM generally and opinion seeking behavior in particular positively and significantly influences purchase decisions. This finding is consistent with previous studies which show that consumers consider word-of-mouth to be a credible source of information about products and brands. This study concludes that marketing practitioners in Botswana should both promote brand-related eWOM among university students and incorporate it in their marketing tools.
\end{abstract}

Keywords: brand-related eWOM, social media, purchase decisions, Botswana

\section{Introduction}

The advent of Web 2.0 technologies in recent years has given rise to the development of Social Media Sites (SMSs) such as YouTube, Twitter and Facebook (Muntinga, Moorman, \& Smit ., 2011; Kaplan \& Haenlein, 2010). These platforms allow users to create and share brand related information online (electronic word-of-mouth or eWOM) in their established social networks which comprise of friends, family classmates and other acquaintances (Hennig-Thurau, Gwinnner, Walsh \& Gremler, 2003; Chu \& Kim, 2011). Past research has shown that such interactions influence consumers' purchase decisions (Muntinga et al., 2011; DEI Worldwide report, 2008), shape brand attitudes (Wu \& Wang, 2011) and affect marketing decisions (Hennig-Thurau et al., 2004). Unlike company generated information, eWOM communication is created and delivered by consumers themselves making it a more credible non-commercial source of information for consumers (Mangold \& Faulds, 2009; Chu \& Kim, 2011). According to Wu \& Wang (2011, consumers rely more on word-of-mouth than on other sources of information when making purchase decisions.

Due to its role in providing consumers with non-commercial information about products and in influencing consumer purchase decisions eWOM has attracted attention from both practitioners and researchers (De Bruyn \& Lilien, 2008). For example, companies are already developing platforms designed to facilitate eWOM relating to their own brands such as discussion boards, customer reviews and other online tools that enable consumers to share information about products and services (Bruyn \& Lilien, 2008). Companies are also said to be moving towards using consumer-to-consumer communications as opposed to company-to-consumer communications to disseminate information about their own products or services (De Bruyn, 2008). According to Grewal \& Levy (2010 p. 534), many firms, especially retailers, encourage customers to post reviews of products they have bought or used and even have visitors to their web sites rate the quality of reviews. Such online product reviews are thought to increase customer loyalty and provide competitive advantage for companies that offer them (Voight, 2007, cited in Grewal \& Levy, 2010 p.537).

Researchers have also shown a keen interest in understanding how consumers engage in eWOM (Wu \& Wang, 2011), the motivations for engaging in eWOM (e.g. Muntinga et al., 2011), the circumstances under which they engage eWOM (Chu \& Kim, 2011) and the effect of eWOM on purchase decisions (Chu \& Kim, 2011; Cheung, Lee \& Rabjohn., 2008; Riegner, 2007). However much of the accumulated knowledge on eWOM is based on 
studies conducted in USA (e.g. Riegner, 2007), Europe (e.g. Hennig-Thurau et al., (2004) and Asia (e.g. Wu \& Wang, 2011). Few, if any, studies have been conducted in Africa, and in the case of Botswana, no such study has been reported to date. This is despite the fact that the internet connects consumers on a global scale enabling brand-related eWOM to take place between consumers in different countries. The paucity of research on eWOM usage in Botswana raises the following important questions:

1) To what extent do Batswana engage in brand-related eWOM via social media? What factors, if any, influence their engagement in brand-related eWOM? Does engagement in eWOM via social media vary according to demographic characteristics of consumers?

2) Does engagement in eWOM via social media influence the purchase decisions of consumers in Botswana? That is, do consumers in Botswana rely on eWOM information to make purchase decisions?

This study seeks to address some of these questions and to contribute to the literature in this area by investigating the extent to which University of Botswana students engage in brand-related eWOM via social media and the effect of such engagement on their purchase decisions. The study focuses on University of Botswana students because young people including university students are at the forefront of social media adoption and usage (Riegner, 2007; Quan-Haase, 2010). Moreover, despite their relatively low purchasing power university students constitute a major consumer segment for a variety of goods and services. Therefore university students are an ideal population for an investigation of issues related to social media use and its influence on consumer behavior. Other scholars have also carried out similar studies among university students (e.g. Hamat, Embi, \& Hassan, 2012; Kamtarin, 2012).

The paper is set out as follows: after the introduction follows literature review, methodology and presentation of the main findings. We then discuss the main findings before presenting the conclusions. Limitations of the study and directions for future research follow next.

\section{Literature Review}

\subsection{Word-of-Mouth (WOM)}

Traditional Word-of Mouth (WOM) has been defined differently by different authors in marketing literature. For example, Arndt (1967) define WOM as an oral form of interpersonal non-commercial communication among acquaintances. Wu \& Wang (2011) on the other hand define WOM as oral person-to-person communication between a receiver and a sender, which involves a product, service or brand. Despite these definitional differences WOM is widely recognized as a non-commercial source of information that has a more persuasive effect on consumer purchase decisions than traditional marketing tools such as personal selling, sale promotions, public relations and conventional advertising (Katz \& Lazarsfeld, 1955; Engel et al. 1969; Cheung et al. 2008). Since the recipient of the message does not consider the messenger to have a commercial intent, WOM is believed to have higher credibility than commercial advertisements (Anderson, 1998; Harrison-Walker, 2001). In a study of the impact of word of mouth in directing the purchasing behavior of Jordanian consumers Zamil (2011), found a significant statistical relationship between buying decision and word of mouth transmitted from one consumer to another. The introduction of internet technologies in recent years has transformed the traditional WOM into a new and more dynamic form - the electronic word-of-mouth or eWOM.

\subsection{Electronic Word-of-Mouth (eWOM)}

According to Henning-Thurau et al. (2004 p. 39) electronic word-of-mouth (eWOM) is "any positive or negative statement made by potential, actual, or former customers about a product or company, which is made available to a multitude of people and institutions via the internet". eWOM occurs via a variety of electronic media including online discussion forums, electronic bulletin board systems, newsgroup, blogs, review sites, and social networking sites (Cheung et al. 2008). These platforms allow "consumers to not only obtain information related to goods and services from the few people they know, but also from a vast, geographically dispersed groups of people, who have experience with relevant products or services" (Cheung et al. 2008 p.230). Unlike traditional WOM, eWOM communication possesses unprecedented speed of diffusion and is more persistent and accessible (Cheung \& Thadani, 2010). Furthermore, eWOM is not restricted to close acquaintances such as friends and family, rather, it can take place between complete strangers who are geographically dispersed (Chu \& Kim, 2011).

According to Fynn et al. (1996) consumer involvement in brand related eWOM via social media is reflected by three set of behaviors: Opinion Seeking (OP), Opinion Giving (OG) and Opinion Passing (OP). Opinion seeking behavior is displayed by consumers who search for information and advice from others when making a purchase decision (Chu \& Kim (2011). Consumers display opinion giving behavior when they share product or brand 
related information, opinions and thoughts with others online. By contrast opinion passing is when an online recipient of information forwards it to others as it is. Due to the dynamic interactivity of the cyberspace, a single person can play multiple roles of opinion provider, seeker and transmitter (Chu \& Kim, 2011).

eWOM has been the subject of much empirical investigations in recent years (e.g. Henning-Thurau et al., 2004; Senecal \& Nantel, 2004; Goldsmith, 2006; Muntinga et al., 2011; Chatterjee, 2011; Chu \& Kim (2011). One of the major issues that have been investigated relates to consumer motivation to engage in brand related eWOM (e.g. Henning-Thurau et al., 2004; Muntinga et al., 2011; Chatterjee, 2011). According to Muntinga et al., 2011, understanding people's motivations to engage in brand-related social media use is imperative as it enables marketers to effectively anticipate and direct consumer responses. Previous studies suggest that consumers who engage in brand-related eWOM are driven by a variety of motives (Henning-Thurau et al., (2004). For example, Henning-Thurau et al., (2004. p. 39) concluded based on their findings that "consumers' desire for social interaction, desire for economic incentives, their concern for other consumers, and the potential to enhance their own self-worth are the primary factors leading to eWOM behavior". Similarly Muntinga et al., (2011) found that consuming, contributing to and creating brand-related content on social media were driven by different motives. For example, they found that consuming brand related content was motivated by the desire to remain aware of what is going on in one's social environment (information), to gain more knowledge and expertise about a product or brand (knowledge), to make informed purchase decisions (pre-purchase information) and the desire for personal inspiration (inspiration) and enjoyment (entertainment) amongst others [for a complete discussion of these and other motives see Muntinga et al., (2011 p. 26-37)]. In a related study Chatterjee (2011) shed further insights into eWOM usage behavior by empirically investigating the propensity of consumers to recommend a brand and generate a referral. The study found that although consumer-generated brand messages are significantly more likely to be recommended they are significantly less likely to generate referrals both for high and low involvement products. From a practitioners' perspective this finding can be considered significant as it highlighted the need to pay particular attention to the potential for eWOM to result in both recommending and referral behaviors (Chatterjee, 2011).

The effect of eWOM on consumer purchase decisions is the other major issue that has attracted much empirical investigations in recent years (e.g. Reigner, 2007; Kamtarin, 2012; Wu \& Wang, 2011). Several studies have suggested that eWOM has a positive influence on purchase decisions (Reigner, 2007; Kamtarin, 2012; Wu \& Wang, 2011). In a study involving over 4000 broadband users in the United States Reigner (2007) found that purchase decisions were influenced by recommendations from family and friends in online word-of-mouth communication. It was further observed in this study that products that are purchased online are twice as likely to be influenced by user generated content as products purchased offline. DEI Worldwide also conducted a study in 2008 to "gain deeper insights into what products or services consumers research online, what online sources they use to gather information, and what they do with the information that they receive" (DEI Worldwide report, 2008 p. 2). According to the findings of this study, online consumers regarded recommendations from other people as valuable and credible sources of information that influenced their purchase decisions (DEI Worldwide Report, 2008). Kamtarin (2012) investigated the effects of eWOM on the purchase intentions of consumers in Canada and produced findings that confirmed the posited relationship.

Other researchers have investigated the effects of message source credibility on eWOM communications. For example, Wu \& Wang (2011) investigated the effect of eWOM message source credibility on brand attitude. Their findings showed that a direct and positive relationship existed between message source credibility and brand trust, brand affection and brand attitude. This finding led them to conclude that high perceived credibility of eWOM message source increased perceived quality, decreased perceive risk and improved brand attitude. This finding also highlights the importance of source credibility in online interpersonal communications (Cheung \& Thadani, 2010).

\subsection{Social Media Usage}

Social media describes internet-based applications that help consumers to share opinions, insights, experiences, and perspectives (Kaplan \& Haenlein, 2009 p. 565). According to Kaplan \& Haenlein, (2010) social media allow internet users to create content about almost anything including organizations, products and brands (Kaplan \& Haenlein, 2010). As such social media constitutes a conduit through which consumers can engage in eWOM. According to Mangold \& Faulds (2009), social media encompasses a variety of online information-sharing platforms such as social networking sites (e.g. Facebook, MySpace, and Friendster), creativity works-sharing sites (e.g. You Tube and Flickr), collaborative websites (e.g. Wikipedia) and micro blogging sites (e.g. twitter). Of the different types of social media, social networking sites (SNSs) have emerged as the most important tools for interacting and socializing (Hamat, et al. (2012). According to Chu \& Kim (2011), SNSs have also emerged 
as a major channel for brand-related consumer-to consumer conversations.

Social media usage has also generated much research interest in recent years. Past research indicates that social media usage varies across different demographic groups (e.g. EDUCAUSE Centre for Applied Research [ECAR] report, 2008), social media sites (e.g. Riegner, 2007) and national contexts (e.g. Ngini, Furnell \& Ghita., 2002). Young aged between 18 and 30 are said to be the most active users of social media (Lenhart, Purcell, Smith \& Zickuhr, 2010). This age group is largely made up of college and university students. Facebook has also been found to be the most popular social media sites among college and university students (Quan-Haase \& Yound, 2010). Ellison et al. (2007) found that over 90 per cent of undergraduate students at Michigan State University were users of Facebook. According to Madge, Meek, Wellens \& Hooley (2009, cited in Hamat et al., 2012), the majority of students use SNSs for social reasons rather than for academic purposes. Research also indicates that usage of social media differs from one national context to another depending on the level of development of internet infrastructure among others (Ngini, 2002). In general developing countries have been found to be lagging behind developed economies in terms of internet infrastructure development (Ngini et al., 2002).

Internet penetration rate in Botswana remains relatively low despite progress made to reduce the cost of connection and improve the country's telecommunications infrastructure (Smarts, 2010; Moreri, Pitso \& Strickley, 2010; Mutula, 2002). Recent statistics indicate that Facebook is the most popular social media in Botswana with over 13 per cent penetration rate and 276, 920 users, the majority of whom are young adults aged between 18 and 24 (Botswana Facebook Statistics, 2012). Based on these statistics one can safely conclude that although internet penetration in Botswana is low, social media use among the young population is relatively high

It is evident from the extant literature reviewed that eWOM has generated much research and practitioner interest. Of particular interest to both researchers and practitioners is the effect of eWOM on purchase decisions (Chu \& Choi 2011). Past research indicates that eWOM has a pervasive influence on consumer purchase decisions. However, most of the accumulated knowledge on eWOM and its posited influence on consumer purchase decisions have been generated from studies conducted outside the African continent in Asia, Europe and North America. The present study seeks to address this paucity of research in Africa and Botswana by empirically investigating the extent to which students at the University of Botswana engage in brand-related electronic word-of-mouth via social media and the influence this is bringing to bear on their purchase decisions.

\subsection{Hypotheses}

Based on the literature reviewed and the researchers' personal insights, the following hypotheses relating to University of Botswana students' engagement in brand-related eWOM via social media are proposed:

H1: Engagement in brand-related eWOM is high.

H2: Overall, brand-related eWOM has a positive and significant influence on purchase decisions.

H3: Opinion seeking behavior positively and significantly influence consumer purchase decisions.

\section{Methodology}

A survey or descriptive research design was used to investigate the extent to which University of Botswana students engage in brand-related eWOM using social media and the influence this is having on their purchase decisions. This choice of research design is consistent with most of the previous studies on social media and its use in brand-related word-of-mouth (e.g. Chu \& Kim, 2011; Zamil, 2011). The survey method was also considered appropriate since the study involves variables and concepts that have been well defined in the literature. Furthermore, the descriptive design was selected because it is suitable for determining the frequency with an activity or behavior occurs and for measuring the relationship between variables (Malhotra, 2009). This study seeks amongst others to determine the frequency which University of Botswana students engage in brand-related eWOM and to determine the relationship between engagement in eWOM and purchase behavior.

Data for the present study was collected from a convenience sample of University of Botswana students, using a structured questionnaire. In line with normal practice, the questionnaire was pre-tested with a small group of students before it was rolled out to business and non-business students. Such a process allows researchers to identify and remove errors and potential sources of misunderstanding among the respondents (Hair et al. 2010). To avoid group influence the students were approached individually by the research assistants at various rest areas within the University of Botswana's main campus. The students were first asked whether they have used social media in the last six months and those who had, were then politely asked to complete the questionnaire in the presence of the research assistant who ensured that questions were answered accurately and adequately. The questionnaire consisted of two sections. In the first section the respondents were required to indicate the social media sites they used, the average time spent per day on social media and the product categories that they 
communicated about on social media. The respondents were then asked to respond to a series of statements relating to their engagement in brand-related opinion seeking, opinion giving and opinion passing behavior. For example, opinion seeking behavior included a statement such as: "When I consider new products, I ask my contacts on SNSs for advice". Similarly, opinion passing behavior included statements such as: "When I receive brand related information or opinion from a friend, I pass it along to my network of friends on social media". Most of the statements were adapted from the literature. The respondents were asked to indicate on a scale ranging from 1 (Strongly Agree) to 6 (strongly Disagree) their level of agreement or disagreement with the statements. These statements were followed by a single question about whether or not eWOM influenced their purchase decisions. The second section covered information relating to the respondents' demographic characteristics. In all 300 usable questionnaires were obtained.

All the questionnaires were coded and entered into the computer for analysis using SPSS statistical software (Version 15.0, 2008; SPSS Inc, Chicago, IL, USA). Data analysis was carried out in several stages. In the first stage data cleaning was performed using SPSS in order to rid the data of spurious responses. Secondly, data was analyzed using descriptive to reveal usage patterns of brand related eWOM via social media among University of Botswana students. This was followed by regression analysis to test the hypothesized relationship between brand-related eWOM and purchase decisions.

\subsection{Measurement}

Drawing from previous studies (e.g. Flynn et al. 1996) engagement in eWOM was operationalized with three specific behaviors: opinion seeking (OS), Opinion Giving (OG) and Opinion Passing (OP). A multi-item scale adopted from $\mathrm{Chu} \& \mathrm{Kim}$ (2011) was used to examine these behaviors. All items were measured on a six point Likert scale anchored by " $1=$ Strongly Agree" and " $6=$ Strongly Disagree". In line with common practice the scale was modified to reflect the local context. The respondents were also asked to self-rate on a scale ranging from very high to very low the level of influence of brand related eWOM has on their purchase behavior.

\subsection{Scale Reliability}

As it is common practice, before testing the hypotheses, the scales were tested for reliability using Cronbach's Alpha (Nannuly, 1967). To ensure homogeneity and internal consistency all items used were examined for correlation-to-total scores. According to Nannuly (1967), items which show item- to-total correlations of less than 0.3 should be deleted. Similarly one may drop an item which if deleted improves overall Alpha. In the present study there was no need to take either of these actions because Alpha coefficients for all the items used exceeded the recommended .70. As reflected in Table 1 below all the Alpha Coefficient exceeds .8 which shows that the scale used has an acceptable level of internal consistency and homogeneity.

Table 1. Dimensional statistics and reliability test

\begin{tabular}{lcccccc}
\hline Dimensions & Mean & Std. Deviation & No. of Items & Min. & Max. & Cronbach's Alpha \\
\hline OS & 3.96 & 1.36 & 3 & 1.00 & 6.00 & .895 \\
OG & 3.92 & 1.25 & 3 & 1.00 & 6.00 & .831 \\
OP & 3.42 & 1.30 & 3 & 1.00 & 6.00 & .843 \\
\hline
\end{tabular}

\section{Results}

\subsection{Respondents' Demographic Profile}

The gender and age makeup of the sample indicates that the majority of the respondents were female (54.7 per cent) and those aged between 21 and 30 years old (58.7\%). This is consistent with the findings of Kamtarin (2012) who conducted a similar study in Vancouver Island and found that most of the respondents were female students aged between 20 and 30 years. The next largest age group is 18 to 20 years old ( 37 per cent). The older age group of 31 and above makes up only 3 per cent of the sampled population. According to Reigner (2007), such disparity between younger and older users reflects a generational divide in Web 2.0 involvement. Regarding the program and level of study our sample consist mostly of students pursuing non-business programs (53 per cent) in their third to fifth level of study (56.6 per cent). With an overwhelming majority of the respondents (92 per cent) indicating that they used it to engage in brand related eWOM, Facebook is the most popular social media site among University of Botswana students. This finding is also consistent with previous studies (ECAR Research Study report, 2008; Chu \& Kim (2011). A majority (53 per cent) of the respondents spend up to two 
hours a day on SMSs, which is both relatively high and consistent with previous studies. For example, in the ECAR Research Study (2008), the majority of the respondents reported spending 5 hours or less per week on SNSs. Our results also indicate that electronic gadgets such as cell phone handsets (29 per cent) and clothes (25 per cent) are the subject of most of the brand-related eWOM conversations among the sampled students. These findings are reflected in table 2 below:

Table 2. Respondents' demographic profile

\begin{tabular}{|c|c|c|c|}
\hline \multicolumn{2}{|l|}{ Variable } & \multirow{2}{*}{$\begin{array}{c}\text { Frequency }(\mathbf{N}=\mathbf{3 0 0}) \\
136\end{array}$} & \multirow{2}{*}{$\begin{array}{c}\text { Per cent } \\
45.3\end{array}$} \\
\hline Gender: & Male & & \\
\hline & Female & 164 & 54.7 \\
\hline Age: & $18-20$ & 112 & 37.3 \\
\hline & $21-30$ & 176 & 58.7 \\
\hline & 31 and above & 12 & 3.0 \\
\hline Program & of Study: Business & 124 & 41.3 \\
\hline & Non-Business & 176 & 58.7 \\
\hline SMSs Us & d: Facebook & 276 & 92 \\
\hline & My Space & 2 & 0.67 \\
\hline & You Tube & 9 & 3.0 \\
\hline & Twitter & 7 & 2.3 \\
\hline & Others & 6 & 2.0 \\
\hline Time Sp & nt on SMSs per day: 2 hours or less & 159 & 53.0 \\
\hline & More than 2 hours & 141 & 47.0 \\
\hline \multicolumn{4}{|c|}{ Product Categories Communicated about on SMSs: } \\
\hline Beauty p & oducts & 54 & 18 \\
\hline Clothes & & 75 & 25 \\
\hline Books & & 59 & 19.7 \\
\hline Music, D & VDs & 25 & 8.3 \\
\hline Electroni & gadgets (e.g. cell phones) & 87 & 29 \\
\hline
\end{tabular}

\subsection{Hypotheses Testing}

We hypothesized in this study that the level of engagement in brand-related eWOM via social media by University of Botswana students is high. We tested this hypothesis using descriptive statistics (Pansiri \& Courvisanos, 2010). To test our hypothesis we calculated the mean for the items making the scale for opinion seeking, opinion passing and opinion giving behaviors. These means were calculated from a possible minimum of 1 and a maximum of 6 . As reflected in table 1 the means for the three behaviors range from 3.42 to 3.96. Based on this finding we can conclude that involvement in brand-related eWOM in Botswana is low. Therefore, $\mathrm{H} 1$ is not supported by the findings.

In order to test hypotheses $2 \& 3$ two separate regression analyses were performed with purchase decision as a dependent variable and the independent variables being opinion seeking and overall eWOM usage. Based on the results of simple regression analyses (table 3) engaging in brand-related eWOM generally has a significant positive effect on purchase decisions $\left(\operatorname{Adj} \mathrm{R}^{2}=0.229\right.$; beta $\left.=0.481 ; \mathrm{p}<0.001\right)$. Similarly the regression results indicate that opinion seeking has a significant positive influence on purchase decisions $\left(\mathrm{R}^{2}=0.187\right.$; beta $=0.435$; $\mathrm{p}<0.001$ ). Therefore based on these results both $\mathrm{H} 2$ and $\mathrm{H} 3$ are confirmed. 
Table 3. Simple regression results

\begin{tabular}{ccc}
\hline & Model 1: & Model 2: \\
& $\mathrm{y}=$ purchase decisions & $\mathrm{y}=$ purchase decisions \\
$\mathrm{X}_{1}=$ OS & OWOM usage \\
\hline $\mathrm{R}^{2}$ & .190 & .232 \\
Adj. $\mathrm{R}^{2}$ & .187 & .229 \\
$\mathrm{DF}$ & 1 & 1 \\
$\mathrm{~F}$ & $68.549^{* * *}$ & $88.409 * * *$ \\
Beta & .435 & $.481^{* * *}$ \\
\hline
\end{tabular}

Note: ${ }^{* * *} \mathrm{P}<.001$; Dependent variable: purchase decisions; independent variables OS; eWOM Usage

\section{Discussions}

The present study investigates the extent to which students at the University of Botswana engage in brand-related eWOM via social media and the effects of such engagement on their purchase decisions. The findings indicate that the level of engagement in brand-related eWOM via social media by University of Botswana students is relatively low. Although this finding was unexpected, it could be explained by the fact that in Botswana as it is in most other developing countries social media is still a relatively new concept that has yet to be fully explored users. Previous studies have also shown that engagement in brand-related eWOM tend to be higher among online than offline purchasers (Riegner, 2007). In Botswana however, most transactions are still done offline. It must be noted however, that although University of Botswana students are not actively engaged in brand-related eWOM, they seem to be highly engaged in other online activities as indicated by the amount of time they spend on SNSs.

Regarding the influence of eWOM on purchase decisions, the findings of the present study indicate that engaging in brand-related eWOM generally and specifically opinion seeking significantly and positively influence purchase decisions. This confirms the findings of previous studies. For example, in a US study DEI Worldwide (2008) found that two thirds of consumers felt that recommendations from other people are a valuable and credible source of information that could influence their purchase decisions. The study further found that consumers who engage in eWOM are more likely to make a purchase decision than those who do not. Similarly, Riegner (2007) found that online recommendations from family and friends influenced 17 per cent of purchases. However, Riegner (2007) also concluded that eWOM is still at an "early adopter" phase influencing particular products and certain purchase channels more than others.

In addition to the main findings discussed above, the present study found that female students and those aged between 20 and 30 are more actively involved in eWOM than other demographic groups investigated. This finding suggests that there might be a gender dimension to the engagement in brand-related eWOM among University of Botswana students. The finding also confirms the widely held view that the youth aged between 18 and 30 are spearheading the adoption and usage of internet technologies (Riegner, 2007). The results of the present study also indicate that Facebook is the most popular social networking sites among the university students, which is consistent with studies conducted in other countries (e.g. ECAR Research Study report, 2008). Furthermore the findings of this study indicate that electronic gadgets followed by clothes are the most popular topics of online discussions. This finding is consistent with Riegner (2007) who found that most of the user generated content related to high tech electronic products such as DVDs and computers. Based on this finding Riegner (2007 p. 442) concluded that the more expensive, the more complicated and the more coveted products are, the more time consumers' devote to research them and considering the views of other buyers prior to purchase.

\section{Conclusions}

Previous studies have indicated that young people including university students use social media as a platform for creating, disseminating and sharing information about brands and that this positively influences their purchase decisions. This study extends research on social media usage in brand related eWOM. Much of the previous research in this area has been conducted outside the African continent in Asia, Europe and North America. This study investigates the extent to which University of Botswana students engage in brand- related eWOM via social media and the extent to which this influences their purchase decisions. Our empirical findings 
indicate that the level of engagement in brand-related eWOM among University of Botswana students is relatively low. The study however indicates that engagement in eWOM in general and specifically opinion seeking has a positive and significant influence on purchase decisions. In other words, the findings indicate that opinion seekers are more likely to be influenced by information obtained from online sources.

The findings of this study highlight the need for companies in Botswana to not only promote the use of social media in brand-related word-of-mouth among university students but also to incorporate social media in their marketing tools. With the proliferation of SNSs and the growing influence eWOM on consumer purchase decisions, companies can derive competitive advantage from harnessing the power of social media as a platform for eWOM. This is important as eWOM is set to eclipse traditional marketing communications tools as the most effective way for a company to engage directly with consumers. However, the low usage of brand-related eWOM among University of Botswana students could also be an indication that its influence is still at an "early adopter" stage, which means that it could take some time before companies can enjoy the full benefits of eWOM.

This study has a few limitations which pave the way for future research. Firstly, the fact that the study focused on University of Botswana students may limit generalizability of the findings to the rest of the population of social media users in Botswana. Similarly, since a non-probability sampling method was used, the sample may not be representative of the entire student population, thus limiting generalizability of the findings. Secondly, the findings of this study are based on respondents' self-report of past eWOM usage and its influence on their purchase behavior. This method has inherent weaknesses associated with erroneous recollection and possible hindsight bias (De Bruyn \& Lilien, 2008). To address this problem Chatterjee (2011) recommends that researchers investigate actual behavior by using clickstream data which is free of reporting or researcher bias. In light of the above limitations, we recommend that future researchers should replicate this study with more representative samples of university students and other demographic segments. It is also recommended that researchers should employ methods of data collection that minimizes recollection and personal bias on the part of the respondents.

\section{References}

Anderson, E. W. (1998). Customer satisfaction and word-of- mouth. Journal of Service Research, 1, 5-17. http://dx.doi.org/10.1177/109467059800100102

Arndt, J. A. (1967). Role of product related conversations in the diffusion of a new product. Journal of Marketing Research, 4, 291-5. http://dx.doi.org/10.2307/3149462

Chang, L., \& Lee, Y. (Undated). The influence of E-Word-Of-Mouth on the Consumer's Purchase Decision: a Case of Body Care Products. Retrieved December 7, 2012, from http://www.jgbm.org/page/2\%20Yu_je\%20Lee.pdf

Chatterjee, P. (2011). Drivers of new product recommending and referral behavior on social network sites. International Journal of Advertising, 30, 77-101. http://dx.org/10.2501/IJA-30-1-077-101

Cheung, C. M. K., \& Thadani, D. R. (2010). The effectiveness of electronic word of mouth communication: A literature Analysis. Retrieved November 30, 2012, from: http://www.domino.fov.uni-mb.si/proceedings.nsf/0/.../\$File/24_Cheung.pdf

Cheung, C. M. K., Lee Mathew, K. O., \& Rabjohn, N. (2008). The impact of electronic word-of mouth: The adoption of online opinions in online customer communities. Internet Research, 18, 229-247. http://dx.org/10.1108/10662240810883290

Chu, S., \& Choi, S. M. (2011). Electronic Word-of-Mouth in Social Networking Sites: A Cross-Cultural Study of the United States and China. Journal of Global Marketing, 24, 263-281. http://dx.doi.org/10.1080/08911762.2011.592461

Chu, S., \& Kim, Y. (2011). Determinants of consumer engagement in electronic word-of-mouth (eWOM) in social networking sites. International Journal of Advertising, 30, 47-75. http://dx.doi.org/10.2501/IJA-30-1-047-075

De Bruyn, A., \& Lilien, G. I. (2008). A multi-stage model of word-of-mouth influence through viral marketing. International Journal of Research in Marketing, 25, 151-163. http://dx.doi.org/10.1016/j.jiresmar.2008.03.004

DEI Worldwide Report. (2008). Engaging consumers online: The Impact of Social Media on Purchasing

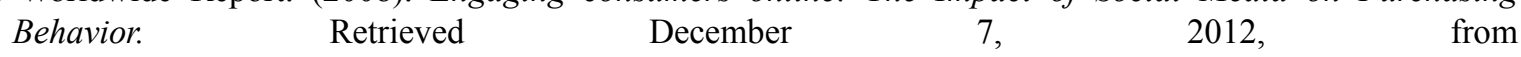


http://www.themarketingguy.files-wordress.com/2008/12/dei-study-engaging.consumers-online

ECAR Research Study. (2008). Social Networking Sites. Students and Information Technology, EDUCAUSE. Retrieved December 7, 2012 from http://www.net.educause.edu/ir/library/pdf/ers0808/rs/ers08086.pdf

Engel, J. F., Blackwell, R. D., \& Kegerreis, R. J. (1969). How information is used to adopt an innovation. Journal of Advertising Research, 9, 3-8.

Flynn, L. R., Goldsmith, R. E., \& Eastman, J. K. (1996). Opinion leaders and opinion seekers: two new measurement scales. Journal of the Academy of Marketing Science, 24, 137-147. http://dx.doi.org/10.1177/0092070396242004

Grewal, D., \& Levy, M. (2010). Marketing (2nd ed.). New York: McGraw-Hill Irwin.

Hair, Jr. J. F., Wolfinbarger, M. F., Ortnau, D. J., \& Bush, R. P. (2010). Essentials of Marketing Research. New York: McGraw-Hill Irwin.

Hamat, A., Embi, M. A., \& Hassan, H. A. (2012). The Use of Social Networking Sites among Malaysian University Students. International Education Studies, 5, 56-66. http://dx.doi.org/10.5539/ies.v5n3p56

Harrison-Walker, L. J. (2001). The measurement of word of mouth communication and an investigation of service quality and customer commitment as potential antecedents. Journal of Service Research, 4, 60-75. http://dx.doi.org/10.1177/109467050141006

Hennig-Thurau, T., \& Walsh, G. (2003). Electronic word-of-mouth: motives for and consequences of reading customer articulations on the internet. International Journal of Electronic Commerce, 8, 54-74.

Hennig-Thurau, T., Gwiner, K. P., Walsh, G., \& Gremler, D. D. (2004). Electronic word-of-mouth via consumer-opinion platforms: What motivates consumers to articulate themselves on the internet? Journal of Interactive Marketing, 18, 38-52. http://dx.doi.org/10.1002/dir.10073

Kamtarin, M. (2012). The effect of Electronic Word of Mouth, Trust and Perceived Value on behavioral Intention from the Perspective of Consumers. International Journal of Academic Research in Economics and Management Sciences, 1, 56-66.

Kaplan, A. M., \& Haenlein, M. (2009). The Fairyland of Second Life: Virtual social worlds and how to use them. Business Horizons, 52, 563-572. http://dx.doi.org/10.1016/j.bushor.2009.07.002

Kaplan, A. M., \& Haenlein, M. (2010). Users of the world, unite! The challenges and opportunities of social media. Business Horizons, 53, 59-68. http://dx.doi.org/10.1016/j.bushor.2009.09.003

Katz, E., \& Lazarsfeld, P. E. (1955). Personal Influence: The part Played by People in the Flow of Mass Communications. Glencoe, IL: The Free Press.

Lenhart, A., Purcell, K., Smith, A., \& Zickuhr, K. (2010). Social media and mobile internet use among teens and young adults. $\quad$ Retrieved $\quad$ November 2012, from http://www.pewinternet.org/ /media//Files/Reports/2010/PIP_Social_Media_and_Young_Adults_Report.pd $\mathrm{f}$

Malhotra, N. K. (2009). Basic Marketing Research ( $3^{\text {rd }}$ ed.). London: Pearson.

Mangold, W. G., \& Faulds, D. J. (2009). Social media: the new hybrid element of the promotion mix. Business Horizons, 54, 357-365. http://dx.doi.org/10.1016/j.bushor.2009.03.002

Moreri, M. M., Pitso, M. R., \& Strickley, A. (2010). A Comparative Study of Access to Web-Enabled Services in Botswana and the UK: Issues, Obstacles and Solutions. In Tatnall, A., \& Kereteletswe, O. C. (Eds.), International Federation for Information Processing 2011, 186-194. Retrieved November 7, 2012, from http://download.springer.com/static/pdf

Muntinga, D. G., Moorman, M., \& Smit, E. G. (2011). Introducing COBRAs; Exploring motivations for brand-related social media use. International Journal of Advertising, 30, 13-46. http://dx.doi.org/10.2501/IJA-30-1-013-046

Mutula, S. M. (2002). Current developments in the internet industry in Botswana. The Electronic Library, 20, 504-511. http://dx.doi.org/10.1108/02640470210454056

Ngini, C. U., Furnell, S. M., \& Ghita, B. V. (2002). Assessing the global accessibility of the Internet. Internet Research: Electronic networking Applications and Policy, 12, 329-338. http://dx.doi.org/10.1108/10662240210438399 
Nunnaly, J. (1967). Psychometric Theory. New York: McGraw-Hill.

Pansiri, J., \& Courvisanos, J. (2010). Attitude to Risk in Technology-Based Strategic Alliances for Tourism. International Journal of Hospitality \& Tourism Administration, 11, 275-302. http://dx.doi.org/10.1080/15256480.2010.498283

Quan-Haase, A., \& Young, A. L. (2010). Uses and Gratifications of Social Media: A Comparison of Facebook and Instant Messaging. Bulletin of Science, technology \& Society, 30, 350-361. http://dx.doi.org/10.1177/0270467610380009

Riegner, C. (2007). Word of Mouth on the Web: The Impact of Web 2.0 on Consumer Purchase Decisions. Journal of Advertising Research, 47, 436-447. http://dx.doi.org/10.2501/S0021849907070456

Smarts, N. (2010, March 03). Botswana's Internet connectivity still low. The Botswana Gazette. Retrieved November 28, 2012 from http://www.gazette

Wu, P. C. S., \& Wang, Y. (2010). The influences of electronic word-of-mouth message appeal and message source credibility. Asia Pacific Journal of Marketing and Logistics, 23, 448-472. http://dx.doi.org/10.1108/13555851111165020

Zamil, A. M. (2011). The Impact of Word of Mouth (WOM) on the Purchasing Decision of the Jordanian Consumer. Research Journal of International Studies, 20, 24-29. 